\title{
Consumer Acceptance of Server Recommendations
}

\author{
Carl P. Borchgrevink \\ Michigan State University \\ Alex M. Susskind \\ Cornell University
}

August 13, 2004

Final version published as: Borchgrevink, C. P., \& Susskind, A. M. (2006) Consumer Acceptance of Server Recommendations, International Journal of Hospitality \& Tourism Administration, 7:4, 21-41, DOI: http://dx.doi.org/10.1300/J149v07n04 02

Carl P. Borchgrevink, PhD, is Associate Professor, The School of Hospitality Business, The Eli Broad Graduate School of Management, Michigan State University.

Alex M. Susskind, PhD, is Associate Professor, School of Hotel Administration, Cornell University.

Address correspondence to: Carl P. Borchgrevink, The School of Hospitality Business, The Eli Broad Graduate School of Management, Michigan State University, East Lansing, MI 48824 USA (E-mail: carlb@bus.msu.edu). 


\begin{abstract}
Servers are typically encouraged to make recommendations and attempt to up-sell. Little is known, however, about the conditions under which restaurant consumers follow server recommendations. We propose considering this from the perspectives of Mertz's work regarding the effect of source evaluations on persuasive influence and Ajzen's theory of planned behavior. Both perspectives yield important insights. Potential research questions are proposed. A few propositions are tested and are generally supportive.
\end{abstract}

KEYWORDS. Persuasion, selling, service, hospitality, restaurants, management 


\section{CONSUMER ACCEPTANCE OF SERVER RECOMMENDATIONS INTRODUCTION}

The academic and trade literature for the most part extols suggestive selling as a critical element in guest satisfaction, increased revenue and server tips (See for example Owen, 2001; Strianese, 1997; Johnson \& Masotti, 1990; Kotschevar \& Luciani, 1996; and Ralis \& O’Brien, 1986). While the literature on occasion points to specific elements as important for persuasive success, the consumer-server exchange has mostly been ignored and many of the suggestions take the form of advice developed without a research foundation. Very little is known about the circumstances that lead a foodservice consumer to accept recommendations proffered by a foodservice employee. Research is needed to increase our knowledge of the potential predictors of foodservice consumers accepting server recommendations. We propose an inquiry using two theoretical frameworks: Mertz's (1966) work on source evaluation and persuasive influence and Ajzen's (1991) Theory of Planned Behavior.

\section{PERSUASIVE INFLUENCE AND SOURCE EVALUATION}

Much research on persuasion has focused on source credibility, i.e., the degree to which the source of the influence attempt is viewed favorably. When a source is viewed favorably, the credibility heuristic (Chaiken, 1987; Cialdini, 1987) suggests that message recipients view the source as trustworthy and dependable and are thus more likely to comply or agree with the source. Perceived source credibility has been found to be related to a variety of variables, such as perceptions of source expertise, verbal fluency and attractiveness, as well as the degree to which the source points to external evidence or is perceived as suggesting a course of action that is counter to expectations from said source (See O'Keefe, 2002; Petty \& Cacioppo, 1996, for a review). As message recipient involvement increases, or their comprehension of subject matter increases, the impact of source credibility is attenuated or non-existent (Ratneshwar \& Chaiken, 1991; Petty, Cacioppo, \& Goldman, 1981) and the recipient tends to focus on the 
content of the persuasive message. This is particularly the case when the message from the source is unambiguous (Chaiken \& Maheswaran, 1994). To the extent that message recipients have the motivation and the cognitive resources to attend to the message, they will consider the message and the arguments embedded in the message. Under these conditions the message recipients are presumably influenced by the quality and quantity of arguments presented (Ajzen \& Fishbein, 2000; Chaiken \& Maheswaran, 1994; Petty \& Cacioppo, 1986). The perceived quality of arguments as presented is likely to be a function of the relative knowledge the receiver perceives the sender to display. That is, if the message establishes that the sender has more topic specific expertise than the recipient, then the perceived quality of the argument should be higher than if the sender is perceived as relatively unknowledgeable. This is consistent with Mertz's (1966) approach to persuasion.

Mertz (1966) proposed that source credibility was based on a multidimensional evaluation of the source and an assessment of the source receiver dyadic relationship. Message source evaluation was seen as based on a consideration of three dimensions, viz. safety, qualification and dynamism. While these dimensions are generally consistent with credibility dimensions offered by other researchers (McCroskey \& Young, 1981), we refer to Mertz's work as he specifically incorporated a consideration of the dyadic relationship between source and single recipient, rather than the traditional one source on many recipients. This dyadic-comparative approach to persuasion has been recognized as an important contribution that has been ignored (Miller, 1987).

Safety refers to the degree to which the source is seen as being predictably and intentionally manipulative. Qualification refers to the source's perceived topic-specific expertise, ability and intelligence. Dynamism refers to the recipients' assessment of the connotative meaning of the source's message, particularly as it reflects the source's activity level and power. To put it differently, dynamism taps the perception of the dynamic, energetic, and vibrant nature of the source. In terms of the dyadic relationship, Mertz (1966) suggested that message 
recipients compare themselves to the source on these three dimensions. To the extent that the source is seen as rating higher than self, the source will be persuasive, while a rating lower than self will lead to a rejection of the influence attempt. From Mertz's (1966) perspective, the credibility of a source is not a function of the source's absolute rating, but is based on the relative credibility rating within the source-recipient dyad. He found support on the dimension of qualification.

\section{Accepting Server Recommendations}

It is a normal part of a server's role to make recommendations to foodservice consumers regarding available food and beverages, and in the process attempt to influence foodservice consumers towards purchasing foods and beverages they recommend. These recommendations may simply enhance the consumer's experience, but will often also lead to an increase in the size or price of the consumer's purchase. Consumers at foodservice establishments would generally expect such behavior and be aware of the server's intent. If a server is perceived as manipulative, however, the server will be less persuasive. This notion of safety, as described by Mertz, is consistent with the propositions of a recent theory known as the Persuasion Knowledge Model (PKM) (Friestad \& Wright, 1994). Broadly, PKM suggests that targets of a persuasion attempt use their knowledge of persuasion attempts in general to assist them in decoding the persuasive message, thus impacting the potential success of the attempt. From this perspective, if a foodservice consumer is faced with a server's persuasive attempt and the server does not behave as expected, or the server behaves in a fashion consistent with past servers perceived as manipulative, the persuasion attempt is likely to fail. The topic specific expertise relevant to a server-consumer interaction is knowledge regarding the particular foods and beverages available for purchase and possibly knowledge of "proper" service procedures and practices. If a foodservice consumer perceives that a server knows more about the available foods and beverages offered for purchase and service procedures than the foodservice consumer does, then the likelihood of server persuasive success is higher than if 
the server is perceived as being less knowledgeable than the foodservice consumer. As the foodservice consumers' subject matter competency, comprehension or involvement increases, they are less likely to be influenced by the credibility heuristic, and will instead focus on the content of the message to the extent that they are able and motivated to do so.

Recommendations that are perceived as demonstrating a lack of competency or lack of knowledge are likely to be rejected.

Server dynamism may vary greatly across servers. It is also likely that the dynamism of a particular server will vary across time and occasion depending on mood, physical energy level, context and more. If a foodservice consumer perceives a server as being more dynamic than the foodservice consumer is, the server is going to be more persuasive than if the foodservice consumer perceived the server as being less dynamic than self. Recommendations made by a server that appears listless and unengaged are likely to be rejected.

\section{PERSUASIVE INFLUENCE AND THE THEORY OF PLANNED BEHAVIOR}

The theory of planned behavior (Ajzen, 1991) is a broad theory that has been found very useful in explaining and predicting human behavior. It is an extension of the theory of reasoned action (Ajzen \& Fishbein, 1980; Fishbein \& Ajzen, 1975). According to the theory, performance of a specific behavior is a joint function of an individual's context specific behavioral intentions and perceived behavioral control. Perceived behavioral control refers to an individual's perceived ease or difficulty in performing the specific behavior in question. When there is no perceived difficulty in performing a behavior, the behavioral intentions predict the behavior with a high degree of accuracy (Ajzen, 1991). Behavioral intentions are seen as determined by three independent variables, one of which is perceived behavioral control. The other two determinants are the attitude towards the behavior and the subjective norm. The attitude towards the behavior refers to the degree to which an individual has a favorable or unfavorable assessment of performing the behavior. The subjective norm refers to the degree to which an individual 
perceives the behavior in question as socially acceptable, i.e., is there social pressure to perform or not perform the behavior? Behavioral intentions are also context specific. From the perspective of the theory of planned behavior, past experiences have been found to have an effect on subsequent behaviors, particularly when the context for enacting the behavior remains the same (Ajzen, 2002; Ajzen \& Fishbein, 2000). If a particular behavior, or a particular behavioral outcome, is deemed positive, a positive attitude towards performing the behavior should form, and the behavior may be repeated (often) when subsequently possible. If the behavior is routinized, it may be performed in an automatic fashion with minimal consideration. A past behavior may, however, also be repeated due to a mindful consideration of past success or the current context. While much evidence exists for the existence of automatic cognitive and evaluative responses, Ajzen and Fishbein (2000) suggest there is scant evidence for automatic behavioral responses.

\section{Accepting Server Recommendations}

The theory of planned behavior suggests that human actions are guided by three beliefs: the behavioral belief, the normative belief and the control beliefs. The behavioral beliefs refer to the anticipated consequences of any given behavior. In our case, the behavior would be accepting server recommendations and the consequence would be the anticipated appropriateness of the recommendation, or to put it more mundanely, the relative success of the recommendation. The normative belief would refer to the degree to which it is appropriate to accept server recommendations and a relevant control belief may be the foodservice consumers' opportunity cost. That is, if the recommended food or wine increases the foodservice consumer check more than foodservice consumers are willing to accept, then foodservice consumers are likely to reject the recommendation. Although there may be some social pressure to accept server recommendations, it is likely that there is much individual variance as to how such pressures are perceived. 
Foodservice consumers who have followed server recommendations in the past will be more inclined to do so again if they experienced the recommendations as satisfactory, but disinclined to follow server recommendations if past experiences were not good. That is, if food and beverages recommended by past servers were generally found by the foodservice consumer to be delicious, to complement the meal as a whole, and not cost more than is acceptable, then the foodservice consumer is likely to continue following such recommendations. If on the other hand, recommendations were followed in the past, but proved to be less satisfactory than anticipated, then the foodservice consumer will be less inclined to follow server recommendations again. A recommendation that is acted upon and experienced as successful by the foodservice consumer should establish a favorable attitude toward server recommendations, predisposing a foodservice consumer to follow server recommendations. Past unsuccessful experiences should have the opposite effect.

While the effects of past experiences are believed to be context specific (Ajzen, 2002; Ajzen \& Fishbein, 2000), the theory does not specify whether the context in this case would refer to a specific foodservice consumer-server relationship, a specific restaurant, a generalized restaurant context, or perhaps a generalized foodservice consumer-server relationship? Nonetheless, research in this area needs to clearly specify the proposed context.

Each of the propositions discussed above are amenable to empirical tests. Some relevant questions that need to be explored are listed in Table 1.

\section{CURRENT STUDY}

Research is needed to test the above propositions and research questions. While we have not yet started a specific research program, we have two data sets from earlier work (Borchgrevink \& Susskind, 1996, 1998/1999) that will allow us to conduct the following secondary research. We need to acknowledge, however, that the data was not collected with 
this particular inquiry in mind. The specific questions we will start to answer are RQ-1, RQ-1.b.i, $R Q-1 . b . i i$, and $R Q-2 . d$.

The original sample was drawn from wine affinity groups, college students of legal drinking age and parents or guardians of undergraduate students that were not of legal age to consume alcoholic beverages. We realize that the samples are not representative of the public at large, and that we will not be able to broadly generalize our findings. On the other hand, both samples were consistent with national averages for restaurant consumers at the time of data collection (National Restaurant Association, 1996; 1999), and found to be slightly above the national socioeconomic level, using Byrne's (1971) measure. The combined sample size is 550. The intent of the original research was (a) to establish the preferences of food service consumers relative to menu language and oral presentations of food and beverages available at foodservice establishments, (b) establish foodservice consumer preference regarding menu format, and (c) establish foodservice consumers' perceptions of server knowledge. The intent of this current research is to have an initial test of support for some of the theoretical propositions that spring forth from the work of Mertz's (1966) or Ajzen (1991), and the data from these two studies should begin to inform us from that perspective.

The data sets include foodservice consumers' perceptions of server expertise and the consumers' tendency to follow server recommendations, making it possible to examine whether a source's relative qualification was important. The content of expertise in this case is beverage knowledge. The specific knowledge domain in question is that of wines offered by a foodservice establishment. In other words, the topic bound expertness (qualification) is beverage knowledge. In addition, we have measures of foodservice consumers' past experiences with following server recommendations, and can examine whether these past experiences had an effect on foodservice consumers' reported general tendencies to follow server recommendations and order the beverages the servers recommend. 


\section{Measurement Instrument}

All items on the questionnaire used in the original research (Borchgrevink\& Susskind, 1996; 1998/1999) were written in Likert-style (1932), using a five point scale, ranging from strongly agree (5), agree (4), neutral (3), disagree (2) to strongly disagree (1). Foodservice consumers' perceptions of server beverage knowledge were assessed across five beverage categories. The foodservice consumers' perception of their knowledge relative to the servers' knowledge and the degree to which the foodservice consumers tend to follow server recommendations (i.e., usually order a recommended beverage) were both measured with single item measures. The success of past recommendations was assessed using a scale measuring the success of beverage recommendations in general, wine recommendations and beer recommendations. Table 2 contains the mean scores for each of these items.

To assess the factor structure, we submitted the scales for foodservice consumers' perception of server knowledge and their perceived success of past recommendations to principal components factor analysis with Varimax rotation. The analysis produced two clear factors, accounting for $56 \%$ of the variance, with no cross loading above .19 . Please see Table 3. This provides evidence of construct validity and supports the use of these two aggregate scales for measuring perceived server knowledge and success of past recommendations. The perceived server knowledge scale obtained a Cronbach (1951) coefficient alpha reliability of .74, while the success of past recommendations scale obtained a Cronbach alpha reliability of .76.

\section{Regression Analyses}

We examined the impact of perceived server knowledge (RQ-1.b.i), perceived relative server knowledge (RQ-1.b.ii) and the success of following past recommendations (RQ-2.d) on the reported tendency to follow server recommendations using simple linear regression. In the first equation we looked at whether foodservice consumers' perceptions of server knowledge would predict their tendencies to follow server recommendations, and found server knowledge to be a predictor $(\beta=.14, p=.00)$ of following server recommendations $(F 1,540]=11.51, p=$ 
$\left..00, R^{2}=.02\right)$. Although server knowledge was predictive of following server recommendations, the $\beta$ and the $R^{2}$ suggests that the model is not strong and explains a very limited amount (2\%) of the variance in following server recommendations.

To see whether foodservice consumers' perceptions of their knowledge relative to the servers would modify the predictive value of server knowledge, we subdivided the sample into two sets: (a) foodservice consumers that perceived themselves as more knowledgeable about wines than the servers and (b) foodservice consumers that perceived themselves as being less knowledgeable about wines than servers. Server knowledge did not predict foodservice consumers' tendency to follow server recommendations for those who identified themselves as being less knowledgeable than the servers about wine $(\beta=.08, p=.23, F[1,206]=1.46, p=$ $.23, R^{2}=.01$ ), while foodservice consumers who perceived themselves as more knowledgeable than the servers about wines were somewhat inclined to follow server recommendations $(\beta=$ $\left..21, p<.00, \mathrm{~F}[1,186]=8.93, p<.00, R^{2}=.05\right)$. This latter model was a better predictor and explained about $5 \%$ of the variance in the measurement of consumers following server recommendations.

In the final equation we considered the degree to which the success of past experiences would predict following server recommendations. The success of past experiences proved to be a powerful predictor $\left(\beta=.43, p<.00, F=[1,540]=123.94, p<.00, R^{2}=.19\right)$ that explained nearly twenty percent of the variance in the measurement of consumers following server recommendations.

\section{Analysis of Variance}

To further assess Mertz's (1966) qualification contention (RQ-1.b.i) we examined the mean responses regarding foodservice consumers tendencies to follow server recommendations. Perceived server knowledge was collapsed into high and low perceived knowledge, while foodservice consumer's knowledge was recoded as higher than, same as, and lower than perceived server knowledge. The mean responses of foodservice consumers' 
tendency to follow server recommendations are reported in Table 4, with the cell sizes reported in parentheses. The range for knowledge scores is from a high of 5 to a low of 1 . The data in Table 4 hint at a potential interaction effect, but the unbalanced cell sizes and the heterogeneous variance of following servers' recommendations across levels of foodservice consumer knowledge can suppress such effects. To compensate for these statistical limitations, we created equal cell sizes from a random selection of 40 cases from each cell. Table 5 displays this data with Hartley's F-max $(6,39)=1.76(p=.01)$, indicating that the variance is now distributed homogeneously. Plots of the data are presented as Figure 1a and Figure 1b.

This data subset was entered into an analysis of variance to examine the statistical differences across the means (see Table 6). The result show a main effect for perceived server knowledge and an interaction effect between perceived server knowledge and foodservice consumers relative knowledge. To consider the interaction further, an analysis of the simple effects (Keppel, 1982) of foodservice consumer relative knowledge and server knowledge was performed. The results show a simple effect of foodservice consumer relative knowledge when server were seen as unknowledgeable about wine with $F(2,234)=2.95, p=.10, \eta^{2}=.03$ and a simple effect of perceived server knowledge when foodservice consumers perceived themselves to be more knowledgeable than the servers $F(1,234)=9.11, p=.01, \eta^{2}=.04$. (see Table 7 and Table 8). While the findings are statistically significant, it is important to note the effect sizes, which suggest that only a minimal amount of the variance has been explained.

\section{DISCUSSION}

Foodservice consumers' perceptions of server knowledge predicted foodservice consumers' tendency to follow server recommendations. This is consistent with the credibility heuristic (Chaiken, 1987; Cialdini, 1987) and RQ-1, although the small amount (2\%) of variance noted in the measurement of consumers following server recommendations explained by perceived server knowledge suggest that additional factors are at play. 
When we divided the foodservice consumers into two groups based on their perceived relative wine knowledge, we found that perceived server knowledge was a poor predictor of the tendency to follow server recommendations for foodservice consumer that believed they were less knowledgeable than the servers were, but revealed a better predictor of the tendency to order a recommended beverage when they perceived they were more knowledgeable about wines than the server. Mertz's (1966) approach suggests that foodservice consumer knowledge relative to the server should affect the degree to which they accept a server's recommendation, however, this finding seems to be counterintuitive. We expected to find that foodservice consumers that perceived the server to be more knowledgeable than them would be more inclined to follow server recommendations than foodservice consumers that perceived the server as less knowledgeable than them. We appear to have found indications of the opposite! Although the direction of the relationship is not as expected, the findings are generally in support of RQ-1.b.

To further test Mertz's (1966) qualification contention we subdivided the tendency to follow server recommendation into a two by three table based on two levels of perceived server beverage knowledge (server knows much and server knows little) and three levels of perceived relative consumer knowledge (foodservice consumer knows less than server, same as server and more than server). This produced a table (Table 4) of means scores of the tendency to follow server recommendations. After adjusting for unequal cell sizes, Table 5 showed an interaction effect between perceived server knowledge and foodservice consumer relative knowledge on following the servers' proffered advice. Specifically, we found that there is no difference in servers' influence based on perceived server competence when foodservice consumers perceive themselves to be as knowledgeable as the server. When foodservice consumers perceive their degree of knowledge to differ from that of the server, however, we find that foodservice consumers' relative knowledge does have an impact. Consistent with Mertz's (1966) expectation, and RQ1.bi, foodservice consumers are less likely to be persuaded by 
servers they perceive as relatively unknowledgeable. This is particularly evident when foodservice consumers perceived themselves to know more than servers. Inconsistent with Mertz's (1966) expectations, however, we found that foodservice consumers that perceived themselves to know more than the servers report a greater tendency to follow the recommendations of servers perceived as knowledgeable than foodservice consumers that perceived themselves to know less than the servers.

To better demonstrate this effect, the data was plotted in two graphs (see Figure 1a and Figure $1 b)$, both with the tendency to follow server recommendations along the y-axis. In Figure 1a, the $x$-axis reflects perceived server knowledge, while the $x$-axis in Figure $1 \mathrm{~b}$ reflects consumer perceived relative knowledge. The intersecting lines in the graphs further revealed an interaction effect. A main effect resulted for perceived server knowledge $(p=.05)$ and an interaction effect $(p=.10)$ resulted for perceived server knowledge and perceived foodservice consumer relative knowledge (see Table 6). To further describe the location of the interaction, an analysis of simple effects was performed. A simple effect $(p=.10)$ was found for foodservice consumer relative knowledge when servers were perceived as unknowledgeable (see Table 7). A second simple effect $(p=.01)$ was found for perception of server knowledge when foodservice consumers perceived themselves to know more than the servers (see Table 8).

Some of these findings are consistent with the expectation set by Mertz (1966) while others are counter to Mertz's (1966) contentions. The knowledge foodservice consumers perceive to have relative to perceived server knowledge does have persuasive impact. When the server is perceived as relatively unknowledgeable, the relationship between the perception of foodservice consumer relative knowledge and persuasive impact is broadly consistent with expectations. However, when the server is perceived to be knowledgeable, the persuasive impact of the server is stronger when the foodservice consumers believe they are more knowledgeable than the server than when they believe the server knows more than they do. While this appears to be totally contrary to expectations, we believe it may be explained by 
foodservice consumers' absolute knowledge and their degree of wine adventurousness. For example, inexperienced consumers of wine may perceive wine in narrow and rigid terms and would be less willing to experiment. They may know what they like and decide to play it safe. They may not know enough about wine to trust or evaluate server recommendations. More experienced consumers of wine, on the other hand, may be more adventurous and willing to experiment by following servers' recommendations and thus test the recommendations, particularly if the server appears to be knowledgeable about the wines in question. Alternatively, it could also be the case that knowledgeable foodservice consumers tend to rely on server's recommendations if they can verify the recommendation through their own experience. That is, if the recommendations made by servers are consistent with what their personal knowledge suggests would be a good match, they are likely to accept the recommendation.

We also had data that described foodservice consumers' past experiences with following servers' recommendations and found those experiences to be the strongest predictor of the tendency to follow servers' recommendations. In other words, if foodservice consumers had followed servers' recommendations in the past and generally found the recommendations to be good, then they had a higher propensity to accept proffered advice. This set of findings is consistent with the expectations based on the theory of planned behavior (Ajzen, 1991; 2002) (RQ-2.e) that suggests past successes are an important predictor of future actions. Foodservice consumers' past experiences with server recommendations influenced their later behavior when faced with server recommendations. Ajzen's theory $(1991 ; 2002)$, would suggest that the impact of past experience on the foodservice consumers' tendencies to follow server recommendations is a result of the attitude formed from past experiences in following recommendations. It should be noted that the respondents were instructed to report their general experience, not the experience at a specific establishment/time.

\section{Limitations}


Foodservice consumers' beverage knowledge relative to servers and foodservice consumers' tendency to follow server recommendations were both assessed with single item measures. This is a limitation in that reliability cannot be established for those two constructs in the traditional manner. Both constructs, however, are unambiguous and narrow, and concerns regarding reliability should therefore be somewhat ameliorated (Sackett \& Larson, 1990). Furthermore, Wanous and colleagues (Wanous \& Reichers, 1996; Wanous, Reichers, \& Hudy, 1997) have established that even for somewhat complex psychological constructs such as job satisfaction, single item measures can offer acceptable representations of concepts, assuming the concepts being measured are direct and narrow in focus. This is not to suggest that future research designed for the purpose of testing the propositions in this paper should use single item measures.

The secondary research was not designed to test Mertz's (1966) or Ajzen's (1991) models, and some of our findings are less robust than desired. That may reflect reality or be an artifact of our design. Much of the variance in foodservice consumers' tendency to follow a servers recommendation remains unexplained. This study had a rather narrow focus on beverage knowledge. The results may be different in regards to server recommendations of a wider range of products.

\section{Future Recommendations}

Research needs to be designed specifically to test Mertz's (1966) and Ajzen's (1991) models. The questions and propositions we discuss above are amenable to more rigorous empirical tests. Others considering the same models may identify additional questions that need answers. The results of subsequent inquiries may prove to have significant practical implications.

Future research should measure foodservice consumers' absolute knowledge, in addition to their perceptions of relative knowledge. It would also be useful to assess the likelihood that a given consumer would desire to purchase wine to begin with. Likewise, the 
concept of wine adventurousness should be explored to see if it could explain some of our counterintuitive findings. Contextual data needs to be explored for potential impact, as it is possible that dining occasion, location, and restaurant type will impact a foodservice consumers desires and intent to follow server recommendations.

Exploring specific foodservice consumer-server interactions could also expand this research. If foodservice organizations could provide data confirming servers' beverage knowledge and their competence in selling wine (such as a skill/knowledge test and data from the restaurants point-of-sale system), this would further enrich the inquiry. A matched sample including foodservice consumers, servers, and more objective organizational measurements will overcome the limitations of using a mono-method, cross-sectional design reported here. Finally, in addition to exploring Mertz's and Ajzen's work fully, the persuasion literature at large should be explored to see if server persuasive success can be explained and predicted further.

To the extent that research is able to identify and track servers' abilities to influence foodservice consumers' purchases, such abilities should also be considered from the perspective of average check, or some other measure of consumer spending. If a positive association can be identified between persuasive success and average check, this line of research would increase substantially in practical and applied value. Such an inquiry could start in an experimental setting, in which server knowledge could be manipulated, so that foodservice consumers' perceptions could be evaluated under varying, yet controlled, conditions.

It would also be useful to explore the above factors from the perspective of the foodservice establishment rather than server as agent of influence. When foodservice establishments propose prix fixe menus, wine and food pairings, or feature specific beverage selections, they are in fact attempting to persuade. Do the propositions put forth relative to servers also apply to foodservice establishments? Do foodservice establishments have credibility distinct from that of the foodservice establishments' servers? To what extent are the 
efforts of foodservice establishments as organizations viewed as reasonable and distinct from those of the foodservice establishments' servers?

\section{Managerial Implications}

While our results are tentative, there are two primary implications for managers. One of them is that it is essential for a foodservice establishment to "get it right" the first time a foodservice consumer visits a foodservice establishment, as our research suggests that foodservice consumers in part base their response on past experience at large. The second potential implication emphasizes the importance of server training relative to the food and beverage selections the establishment offers, as servers perceived as knowledgeable in the general case were more successful in having their recommendations adopted than servers that were perceived as (relatively) unknowledgeable. 


\section{REFERENCES}

Ajzen, I. (1991). The theory of planned behavior. Organizational Behavior and Human Decisions Processes, 50(2), 179-211.

Ajzen, I. (2002). Residual effects of past on later behavior. Habituation and reasoned action perspectives. Personality and Social Psychology Review, 6(2), 107-122.

Ajzen, I., \& Fishbein, M. (2000). Attitudes and the attitude-behavior relations: Reasoned and automatic processes. In W. Stroebe \& M. Hewstone (Eds.), European review of social psychology (pp. 1-33). Chichester, England: John Wiley \& Sons. Volume 11.

Ajzen, I.,\&Fishbein, M. (1980). Understanding attitudes and predicting social behavior. Englewood Cliffs, NJ: Prentice-Hall.

Borchgrevink, C. P., \& Susskind, A. M. (1996). Beverage communication: A pilot study of the experiences and preferences of restaurant customers. The Hospitality and Tourism Educator, 8(1), 19-23.

Borchgrevink, C. P., \& Susskind, A. M. (1998/1999). Beverage communication at mid-priced, casual theme restaurants: Guest experiences and preferences. Praxis: The Journal of Applied Hospitality Management, 1(2), 92-116.

Byrne, D. (1971). The attraction paradigm. New York, NY: Academic Press, Inc.

Chaiken, S. (1987). The heuristic model of persuasion. In M. P. Zanna, J.M. Olsen \& C. P. Herman (Eds.), Social influence: The Ontario symposium (pp. 3-39). Hillsdale, NJ: Lawrence Erlbaum. Volume 5.

Chaiken, S., \& Maheswaran, D. (1994). Heuristic processing can bias systematic processing: Effects of source credibility, argument ambiguity and task importance on attitude judgments. Journal of Personality and Social Psychology, 41(5), 847-855. 
Cialdini, R. B. (1987). Compliance principles for compliance professionals. In M. P. Zanna, J. M. Olsen \& C. P. Herman (Eds.), Social influence: The Ontario symposium (pp. 165-184). Hillsdale, NJ: Lawrence Erlbaum. Volume 5.

Cronbach, L. J. (1951). Coefficient alpha and the internal structure of tests. Psychometrika, 16(3), 297-334.

Fishbein, M., \& Ajzen, I. (1975). Belief, attitude, intention and behavior: An introduction to theory and research. Reading, MA: Addison-Wesley.

Friestad, M.,\&Wright, P. (1994). The persuasion knowledge model: How people cope with persuasion attempts. Journal of Consumer Research, 21(1), 1-31.

Johnson, C. M., \& Masotti, R. M. (1990). Suggestive selling by waitstaff in family-style restaurants: An experiment and multi-setting observation. Journal of Organizational Behavior Management, 11(1), 35-54

Keppel, G. (1982). Design and analysis: A researcher's handbook (2nd ed.). Englewood Cliffs, NJ: Prentice-Hall, Inc.

Kotschevar, L. H.,\&Luciani, V. (1996). Presenting service: The ultimate guide for the foodservice professional. Chicago, IL: The Educational Institute of the National Restaurant Association.

Likert, R. (1932). A technique for the measurement of attitudes. Archives of Psychology, 140, $44-53$.

McCroskey, J. C., \& Young, T. J. (1981). Ethos and credibility: The construct and its measurement after three decades. The Central States Speech Journal, 32, 24-34.

Mertz, R. J. (1966). Acceptance of persuasive influence as related to three dimensions of source evaluation. (Doctoral dissertation, Michigan State University, 1966). Dissertation Abstracts International, 27(12a), 4340.

Miller, G. R. (1987). Persuasion. In C. R Berger \& S. H.Chaffee, (Eds.), Handbook of Communication Science (pp. 446-483). Newbury Park, CA: Sage Publications. 
National Restaurant Association. (1996). Restaurant spending: Consumer expenditures on food away from home. Washington, DC: Author.

National Restaurant Association. (1999). Restaurant spending. Washington, DC: Author.

O'Keefe, D. J. (2002). Persuasion: Theory and research (2nd ed.). Thousand Oaks, CA: Sage Publications.

Owen, B. (2001). Sell up: Build check averages with suggestive selling and effective marketing. Restaurant Marketing. Retrieved April 12, 2004 from www.restaurantmarketing.net/magazine/March01/sell.html.

Petty, R. E. \& Cacioppo, J. T (1986). The elaboration likelihood model of persuasion. In L. Berkowitz (Ed.), Advances in experimental social psychology (pp. 123-205). San Diego, CA: Academic Press.

Petty, R. E., \& Cacioppo, J. T. (1996). Attitudes and persuasion: Classic and contemporary approaches. Boulder, CO: Westview Press.

Petty, R. E., Cacioppo, J. T., \& Goldman, R. (1981). Personal involvement as a determinant of argument-based persuasion. Journal of Personality and Social Psychology, 41(5), 847855.

Ralis, M. T., \& O’Brien, R. M. (1986). Prompts, goal setting and feedback to increase suggestive selling. Journal of Organizational Behavior Management, 8(1), 5-18.

Ratneshwar, S., \& Chaiken, S. (1991). Comprehension's role in persuasion: The case of its moderating effect on the persuasive impact of source cues. Journal of Consumer Research, 18(1), 52-62.

Sackett, P. R., \& Larson, J. R. Jr. (1990). Research strategies and tactics in industrial and organizational psychology. In D. Dunnette\&L. M. Hough (Eds.), Handbook of Industrial and Organizational Psychology Vol. 1 (2nd ed., pp. 419-489). Palo Alto, CA: Consulting Psychologists Press. 
Strianese, A. J. (1997). Dining room and banquet management (2nd ed.). Albany, NY: Delmar Publishers.

Wanous, J. P., \& Reichers, A. E. (1996). Estimating the reliability of a single-item measure. Psychological Reports, 78(2), 631-634.

Wanous, J. P., Reichers, A. E., \& Hudy, M. J. (1997). Overall job satisfaction: How good are single-item measures? Journal of Applied Psychology, 82(2), 247-252. 
Table 1. Research Questions

1. Does Mertz's approach to persuasion explain and predict when server recommendations are followed or rejected by restaurant consumers?

Specifically:

a. Is the credibility heuristic relevant for the food service consumer-server relationship? That is, do consumers generally perceive servers as credible, and is such credibility a factor in food service consumers ' acceptance of server recommendations?

i. If foodservice consumers perceive servers as credible, can such credibility be attributed to the same variables that general persuasion research have found to lead to perceived credibility of message source? For example, is server credibility a function of server loquaciousness, server attractiveness, the number of arguments presented by a server, or server perceived altruism?

b. Are servers perceived as being knowledgeable regarding the products/services they provide?

i. Does perceived server expertise have a general persuasive effect?

ii. Does the perceived relative (server versus food service consumer) knowledge of servers have a persuasive effect?

iii. Does the absolute relative knowledge of servers have a persuasive effect?

iv. Does the content of server persuasive messages have a persuasive effect?

c. Does the perception of the server as influence agent have an effect?

i. If a server is perceived as manipulative, will the persuasive message be disregarded?

ii. If a server is perceived to act inconsistent with other servers, or other agents of persuasion, will this have a persuasive effect?

d. Does the dynamism of servers have a persuasive effect?

i. Are servers perceived as energetic more persuasive than those perceived as non-energetic?

ii. Are servers perceived as vibrant more persuasive than those perceived as non-vibrant?

iii. What other variables of a dynamic nature have a persuasive effect?

iv. Does the perceived relative (server versus consumer) dynamism of servers have a persuasive effect?

2. Does the Theory of Planned Behavior explain and predict when server

recommendations are accepted or rejected by restaurant consumers?

Specifically:

a. Is it normative to accept server recommendations?

i. If it is normative to accept server recommendations, are there conditions under which the subjective norm varies? If so, what are these conditions?

ii. When a server makes a recommendation, do consumers feel pressured to accept or reject the recommendation? 
1. If such pressure is felt, from whom does the consumer feel this pressure? That is, who are the consumers' referent others?

iii. Does the subjective norm predict the intention to follow server recommendations?

b. Do foodservice consumers develop generalized attitudes regarding the accepting of server recommendations? That is, is the general act of accepting server recommendations positively or negatively valued?

i. Do consumers associate a specific set of behavioral outcomes with the accepting of server recommendations?

ii. Are past experience with following server recommendations predictive of current attitudes towards accepting server recommendations?

1. For example, is past success in following server recommendations related to a positive attitude towards acceptance of server recommendations?

c. Do food service consumers have perceived behavioral control relative to accepting server recommendations?

i. What are the parameters of such control? For example, is the added cost associated with accepting server recommendations an impediment to accepting such?

1. Can a generalized cost increase threshold be identified, beyond which recommendations will be rejected?

d. What are the contexts in which the Theory of Planned Behavior can explain and predict food service consumers' acceptance of server recommendations?

i. For example, is the context server specific, food service segment specific, occasion specific, or perhaps specific to the generalized food service consumer-server context?

e. Is past success in following servers' recommendations predictive of future behavior? 
Table 2. Knowledge and Success Scale Item Mean Scores

\begin{tabular}{|l|l|}
\hline Item & Mean \\
\hline $\begin{array}{l}\text { 1. It has been my experience that service employees know a great deal about the } \\
\text { beverage choices available. }\end{array}$ & 3.31 \\
\hline $\begin{array}{l}\text { 2. It has been my experience that service employees know a great deal about the } \\
\text { wine choices available. }\end{array}$ & 2.74 \\
\hline $\begin{array}{l}\text { 3. It has been my experience that service employees know a great deal about the } \\
\text { beer choices available. }\end{array}$ & 3.65 \\
\hline $\begin{array}{l}\text { 4. It has been my experience that service employees know a great deal about the } \\
\text { spirit choices available. }\end{array}$ & 3.18 \\
\hline $\begin{array}{l}\text { 5. It has been my experience that service employees know a great deal about the } \\
\text { non-alcoholic beverage choices available. }\end{array}$ & 3.91 \\
\hline $\begin{array}{l}\text { 6. The beverage suggestions that service employees make usually match my food } \\
\text { choices well. }\end{array}$ & 3.20 \\
\hline $\begin{array}{l}\text { 7. The wine suggestions that service employees make usually match my food } \\
\text { choices well. }\end{array}$ & 3.25 \\
\hline $\begin{array}{l}\text { 8. The beer suggestions that service employees make usually match my food } \\
\text { choices well. }\end{array}$ & 3.11 \\
\hline $\begin{array}{l}\text { 9. I usually know more about the beverages a restaurant offers than the service } \\
\text { employees do. }\end{array}$ & 3.01 \\
\hline 10. I usually order a recommended beverage. & 2.93 \\
\hline
\end{tabular}

$\mathrm{N}=543$ (listwise deletion).

Likert-style (1932) scale was used, ranging from strongly agree (5), through agree (4), neutral (3), and disagree (2) to strongly disagree (1). 
Table 3. Knowledge and Success Factor Analysis

\begin{tabular}{|l|c|c|}
\hline Item & $\begin{array}{c}\text { Server } \\
\text { Knowledge } \\
\underline{\alpha}=.74\end{array}$ & $\begin{array}{c}\text { Success of Past } \\
\text { Recommendations } \\
\underline{\underline{\alpha}}=.76\end{array}$ \\
\hline $\begin{array}{l}\text { 1. It has been my experience that service employees know } \\
\text { a great deal about the beverage choices available. }\end{array}$ & .80 & .11 \\
\hline $\begin{array}{l}\text { 2. It has been my experience that service employees know } \\
\text { a great deal about the wine choices available. }\end{array}$ & .69 & .19 \\
\hline $\begin{array}{l}\text { 3. It has been my experience that service employees know } \\
\text { a great deal about the beer choices available. }\end{array}$ & .74 & .06 \\
\hline $\begin{array}{l}\text { 4. It has been my experience that service employees know } \\
\text { a great deal about the spirit choices available. }\end{array}$ & .71 & .09 \\
\hline $\begin{array}{l}\text { 5. It has been my experience that service employees know } \\
\text { a great deal about the non-alcoholic beverage choices } \\
\text { available. }\end{array}$ & .51 & .06 \\
\hline $\begin{array}{l}\text { 6. The beverage suggestions that service employees make } \\
\text { usually match my food choices well. }\end{array}$ & .13 & .86 \\
\hline $\begin{array}{l}\text { 7. The wine suggestions that service employees make } \\
\text { usually match my food choices well. }\end{array}$ & .09 & .85 \\
\hline $\begin{array}{l}\text { 8. The beer suggestions that service employees make } \\
\text { usually match my food choices well. }\end{array}$ & .12 & .71 \\
\hline
\end{tabular}

$\mathrm{N}=536$ 
Table 4. Foodservice Consumer Tendency to Follow Server Recommendations (Mean Scores)

\begin{tabular}{|l|c|l|c|}
\hline & $\begin{array}{l}\text { Consumer Perceived } \\
\text { to Know Less Than } \\
\text { The Server }\end{array}$ & $\begin{array}{l}\text { Consumer Perceived } \\
\text { to Know Same } \\
\text { Amount as The } \\
\text { Server }\end{array}$ & $\begin{array}{l}\text { Consumer Perceived } \\
\text { to Know More Than } \\
\text { The Server }\end{array}$ \\
\hline $\begin{array}{l}\text { Perception that } \\
\text { Server Knows Little }\end{array}$ & $2.89(81)$ & $2.96(69)$ & $2.68(146)$ \\
\hline $\begin{array}{l}\text { Perception that } \\
\text { Server Knows Much }\end{array}$ & $3.11(130)$ & $3.01(75)$ & $3.04(48)$ \\
\hline
\end{tabular}

Cell sizes are in the parentheses 
Table 5. Foodservice Consumer Tendency to Follow Server Recommendations (Mean Scores)

\begin{tabular}{|l|c|c|c|}
\hline & $\begin{array}{l}\text { Consumer Perceived } \\
\text { to Know Less Than } \\
\text { The Server }\end{array}$ & $\begin{array}{l}\text { Consumer Perceived } \\
\text { to Know Same } \\
\text { Amount as The } \\
\text { Server }\end{array}$ & $\begin{array}{l}\text { Consumer Perceived } \\
\text { to Know More Than } \\
\text { The Server }\end{array}$ \\
\hline $\begin{array}{l}\text { Perception that } \\
\text { Server Knows Little }\end{array}$ & 2.87 & 2.95 & 2.50 \\
\hline $\begin{array}{l}\text { Perception that } \\
\text { Server Knows Much }\end{array}$ & 2.97 & 2.95 & 3.10 \\
\hline
\end{tabular}

Cell size $=40$ 
Table 6. Analysis of Variance of Foodservice Consumer and Server Knowledge

\begin{tabular}{|l|r|r|r|r|}
\hline & $\underline{\mathrm{SS}}$ & $\underline{\mathrm{df}}$ & $\underline{\mathrm{MS}}$ & $\underline{\mathrm{F}}$ \\
\hline $\begin{array}{l}\text { Foodservice Consumer Relative } \\
\text { Knowledge (A) }\end{array}$ & 1.03 & 2 & 0.515 & 0.65 \\
\hline Perceived Server Knowledge (B) & 3.26 & 1 & 3.26 & $4.13^{*}$ \\
\hline $\mathrm{A} \times \mathrm{B}$ & 4.14 & 2 & 2.07 & $2.62^{* *}$ \\
\hline $\mathrm{S} / \mathrm{AB}$ & 184.75 & 234 & .79 & \\
\hline Total & 193.18 & 239 & & \\
\hline
\end{tabular}

${ }^{*} \underline{p}=.05,{ }^{* *} \underline{p} .10$ 
Table 7. Analysis of Simple Effects of Consumer Relative Knowledge

\begin{tabular}{|l|r|r|r|r|}
\hline & $\underline{\text { SS }}$ & $\underline{\text { df }}$ & $\underline{\text { MS }}$ & $\underline{F}$ \\
\hline $\begin{array}{l}\text { Foodservice Consumer Relative } \\
\text { Knowledge @ Server Perceived as } \\
\text { Unknowledgeable }\end{array}$ & 4.655 & 2 & 2.33 & $2.95^{*}$ \\
\hline $\begin{array}{l}\text { Foodservice Consumer Relative } \\
\text { Knowledge @ Server Perceived as } \\
\text { Knowledgeable }\end{array}$ & 0.517 & 2 & 0.26 & 0.33 \\
\hline S/AB & & 234 & .79 & - \\
\hline
\end{tabular}

${ }^{*} \underline{p}=.10$ 
Table 8. Analysis of Simple Effects of Perceived Server Knowledge

\begin{tabular}{|l|r|r|r|c|}
\hline & \multicolumn{1}{|c|}{ SS } & \multicolumn{1}{c|}{ df } & MS & \multicolumn{1}{|c|}{} \\
\hline $\begin{array}{l}\text { Perception of Server Knowledge @ Foodservice } \\
\text { Consumer Knows Less than Server }\end{array}$ & 0.20 & 1 & 0.20 & 0.25 \\
\hline $\begin{array}{l}\text { Perception of Server Knowledge @ Foodservice } \\
\text { Consumer Knows the Same Amount as the } \\
\text { Server }\end{array}$ & 0.0 & 1 & 0.0 & -- \\
\hline $\begin{array}{l}\text { Perception of Server Knowledge @ Foodservice } \\
\text { Consumer Knows More than Server }\end{array}$ & 7.2 & 1 & 7.2 & $9.11^{*}$ \\
\hline S/AB & & 234 & .79 & \\
\hline
\end{tabular}

${ }^{*} \underline{p}=.01$ 
Figure 1A. Tendency to Order a Recommended Beverage

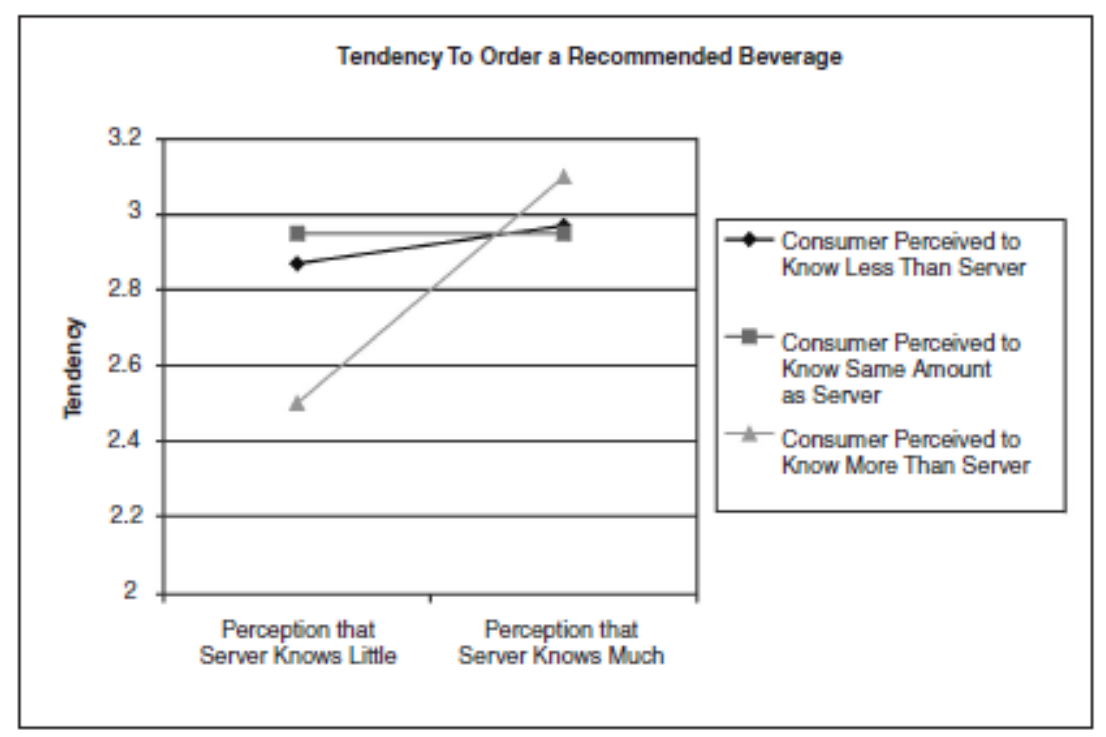

Figure 1B. Tendency to Order a Recommended Beverage

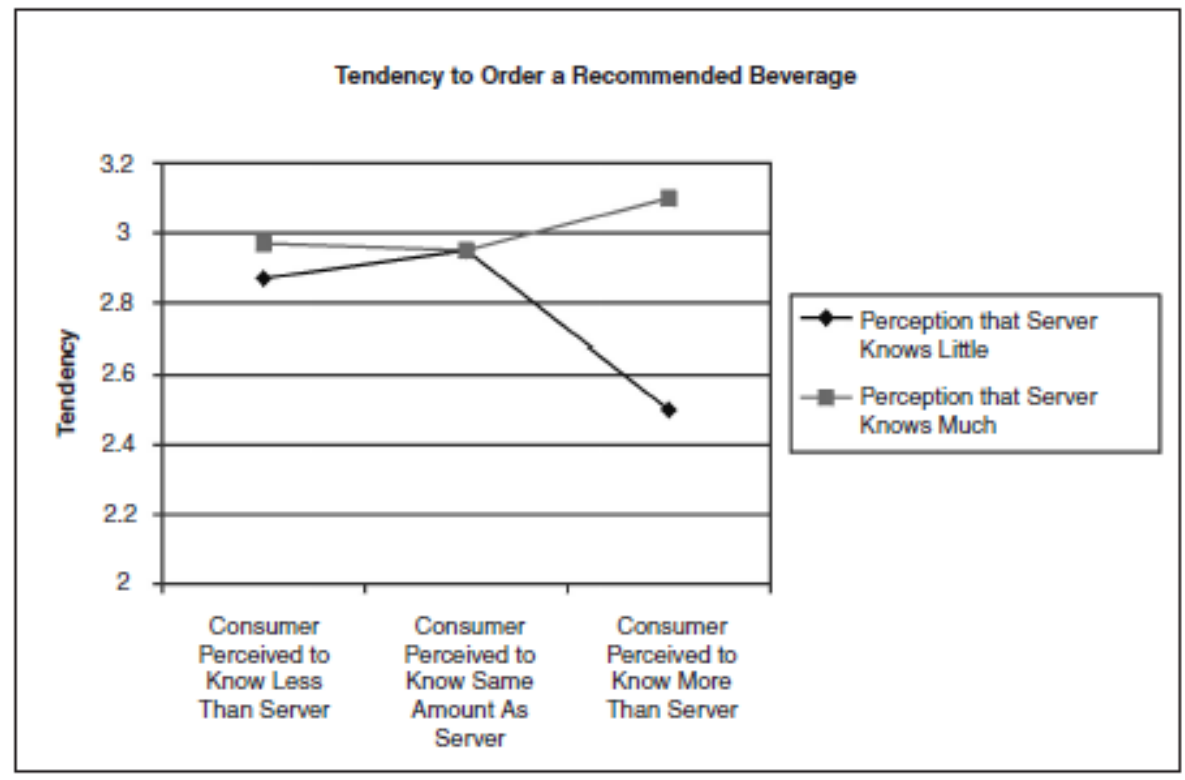

